\title{
INTERACTIONS OF BIOCHAR AND ORGANIC COMPOUND FOR SEEDLINGS PRODUCTION OF Magonia pubescens A. St.-Hil. ${ }^{1}$
}

\author{
Stefany Lorrayny Lima ${ }^{2}$, Suelen Tamiozzo ${ }^{3}$, Edwin Camacho Palomino ${ }^{4}$, Fabiano André Petter ${ }^{5}$ e Ben Hur
} Marimon-Junior ${ }^{6}$

\begin{abstract}
The objective of this study was to test the hypothesis that biochar, applied with cattle manure, promotes better development of seedlings of Magonia pubescens St. Hil. The experiment was conducted at the State University of Mato Grosso, Nova Xavantina, Brazil, in 2011. We used a completely randomized design, with twelve treatments and three replications. The substrates formed by the higher levels of cattle manure plus biochar (30\%) provided better results of height, diameter and aerial biomass. However, the Dickson Quality Index has not confirmed the quality of seedlings in these treatments. We also observed that the doses of biochar (20 and 30\%) when added separately to the Latosol, are not efficient for the growth improvement of the seedlings. Based on the present results, we validate the hypothesis that substrates formed with a mixture of cattle manure and biochar are effective to improve the production of seedlings of $M$. pubescens.
\end{abstract}

Keywords: Tingui; Cerrado; Cattle manure.

\section{INTERAÇÃO ENTRE BIOCHAR E COMPOSTO ORGÂNICO NO DESENVOLVIMENTO DE MUDAS DE Magonia pubescens A. St.-Hil.}

\begin{abstract}
RESUMO - Este trabalho teve como objetivo testar a hipótese de que o biochar (carvão vegetal), aplicado em conjunto com compostos orgânicos como esterco bovino, promove melhor desenvolvimento de mudas de Magonia pubescens St. Hil. O experimento foi realizado na Universidade do Estado de Mato Grosso, em Nova Xavantina, MT, em 2011. Utilizou-se o delineamento inteiramente casualizado, com 12 tratamentos e três repetições. Os substratos formados pelas maiores doses de esterco bovino e biochar (30\%) promoveram os melhores resultados quanto aos parâmetros altura, diâmetro e biomassa aérea. No entanto, a qualidade das mudas nesses tratamentos não foi comprovada pelo Índice de Qualidade de Dickson. Também, observouse que as doses de biochar (20 e 30\%), quando adicionadas isoladamente ao Latossolo, não são eficientes para as características de crescimento das mudas. Com os resultados observados, validou-se a hipótese de que substratos formados com a adição de doses de esterco bovino e biochar são eficientes para a produção de mudas de M. pubescens.
\end{abstract}

Palavras-chave: Tingui; Cerrado; Esterco bovino.

\footnotetext{
${ }^{1}$ Recebido em 02.08.2013 aceito para publicação em 25.03.2015.

${ }^{2}$ Universidade do Estado de Mato Grosso, Programa de Pós Graduação em Ecologia e Conservação, Nova Xavantina, MT

- Brasil. E-mail: <stefany_sll@hotmail.com>.

${ }^{3}$ Universidade do Estado de Mato Grosso, Departamento de Agronomia, Nova Xavantina, MT - Brasil. E-mail: <su_tamiozzo@hotmail.com>.

${ }^{4}$ Universidade Federal do Oeste do Pará, PA - Brasil. E-mail: <edwincamacho2@yahoo.com>.

${ }^{5}$ Universidade Federal de Mato Grosso, Instituto de Ciências Agrárias e Ambientais, ICAA, Sinop, MT - Brasil. E-mail: <petter@ufmt.edu.br>.

${ }^{6}$ Universidade do Estado de Mato Grosso, Departamento de Ciências Biológicas, Programa de Pós Graduação em Ecologia e Conservação- Nova Xavantina, MT - Brasil.E-mail: <bhmjunior@gmail.com>.
} 


\section{INTRODUCTION}

Brazil has the world's greatest biological diversity, with six different biomes over its large territorial extension (SOUZA; FELFILI, 2006). The Cerrado Biome features biological abundance, including several species with broad wood, medicine and decorative potential (ALMEIDA et al.,1998). According to Artur et al. (2007), the need for reforestation has increased the demand of native forest species seedlings, as, in addition to the economic and environmental potential, their propagation out of natural conditions is a feasible process to cover for such increase (MELO et al., 1998).

Among the native forest species of Cerrado, Magonia pubescens St. Hil (tingui), has great commercial use potential, as it may be applied to different activities, as civil construction, furniture manufacturing and coal production (ALMEIDA et al., 1998), besides the pharmacological use (SOUZA; FELFILI, 2006). Its seeds are used for making soap and, together with its fruits, are applied in handicraft (ALMEIDA et al., 1998; CAMPOS FILHO, 2009). The tree serves also as decorative plant, due to the lace-like aspect of its leafs, and is an excellent option for planting in degraded areas, especially those of permanent preservation (MACEDO et al., 2009). Thus, this species represents an alternative for both environmental recovery and commercial cultivations.

However, the challenge of producing vigorous seedlings with good root/air part ratio of native species in the Cerrado Biome is still persisting, since those plants need to face the months of draught in the region, for commercial plantings or recovery of degraded areas. For that, new techniques should be tested in the production of seedlings in nursey, aiming at improving their quality for increased resistance to stress in field.

Recently, the studies on the use of vegetal coal in the agricultural production systems have been intensified.The product, named as biochar (LEHMANN; JOSEPH, 2009), is of slow mineralization, powered by its high C:N ratio (BENITES et al., 2009), which makes it more stable in the soil-plant system (LEHMANN; JOSEPH, 2009). In addition, its intrinsic chemical characteristics, such as the high cationic exchange capacity, can promote a relevant increase in the availability of nutrients on the soil (GLASER et al., 2002; LIANG et al., 2006) and water retention, improving also the cycle of nutrients and contributing to reduce the number of cations lost by lixiviation(GLASER etal., 2002; LEHMANN,
2007; LEHMANN; JOSEPH, 2009). Those characteristics, together with the capacity of increasing the soil $\mathrm{pH}$, result in a significant improvement of soil fertility, in direct benefit of the growth of plants and cultures productivity (GLASER et al., 2002). Another advantage of using biochar is that it can contribute to reduce the $\mathrm{CO}_{2}$ concentration on the atmosphere, since it acts as a resilient stock of carbon to be added to the soil (GLASER et al., 2002; LEHMANN; JOSEPH, 2009).

The benefits of the product to the plant production justify studies testing biochar as a soil or substrate conditioner to improve the quality of seedlings and fertilizer economy. Some studies argue that biochar has no ability to directly provide nutrients to the plants, resulting in low efficiency when the product is tested in isolation (LIMA et al., 2013a; WINSLEY, 2007). Other studies show that biochar, when added to a source of nutrients, improves the development and yield of different crops (GLASER et al., 2002; STEINER et al., 2007; GASKIN et al., 2010). However, only a few works have tested the effect of Biochar together with different sources of nutrients (LIMA et al., 2013b). This study intends to assess the effect of different doses of biochar and cattle manure in the production of $M$. pubescens seedlings, by testing the hypothesis that such association results in synergy between both materials, promoting an improved development of seedlings.

\section{MATERIALAND METHODS}

The experiment was performed in the seedlings nursery of the State University of Mato Grosso (UNEMAT), city of Nova Xavantina (14 $41^{\circ}$ ' 25' $\mathrm{S}$; $52^{\circ} 20^{\prime} 55^{\prime \prime} \mathrm{W}$ ), from March to August 2011. The seeds were collected from Cerrado areas in Parque do Bacaba, owned by UNEMAT in Nova Xavantina. The seedlings were made in $20 \times 30 \mathrm{~cm}$ black polyethylene bags, with side holes for draining the water in excess. A seed was placed in each bag, under the substrate and covered with a thin layer of sawdust to make germination easier. The polyethylene bags were organized on benches over iron support at $1.20 \mathrm{~m}$ high with shadow protection at $50 \%$, chapel model. Irrigation was performed by the micro-aspersion system, with watering shift and application rate under the climate conditions.

The completely randomized design was applied, with twelve treatments and three repetitions. Each repetition required 10 seedlings, totaling 30 seedlings per treatment. 
Substrate mixtures were made of different dosages of biochar and dystrophic Red Latosol (20 and 30\%) and different proportions of cattle manure $(10,20$ and $30 \%$ ). In total, twelve treatments were tested: Test (Red Latosol); CM10 (Red Latosol + cattle manure at 10\%); CM20 (Red Latosol + cattle manure at 20\%); CM30 (Red Latosol + cattle manure at 30\%); BC20 (Red Latosol + biochar at 20\%); BC30 (Red Latosol + biochar at 30\%); CM10+BC20 (Red Latosol + cattle manure at $10 \%$ + biochar at 20\%); CM20+BC20 (Red Latosol + cattle manure at 20\% + biochar at 20\%); CM30+BC20 (Red Latosol + cattle manure at 30\% + biochar at 20\%); CM10+BC30 (Red Latosol + cattle manure at $10 \%+$ biochar at 30\%); CM20+BC30 (Red Latosol + cattle manure at 20\% + biochar at 30\%); and CM30+BC30 (Red Latosol + cattle manure at 30\% + biochar at $30 \%$ ).

The materials used in the formation of substrates were analyzed with regard to the chemical characteristics. For the Red Latosol one obtained the results $\mathrm{pH} 4.5$

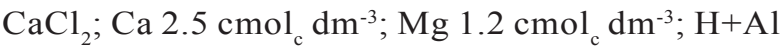
$8.7 \mathrm{cmol} \mathrm{dm}^{-3}$; CTC $12.5 \mathrm{cmol}_{\mathrm{c}} \mathrm{dm}^{-3}$; P $18.5 \mathrm{mg} \mathrm{dm}^{-3}$; $\mathrm{K} 24.0 \mathrm{mg} \mathrm{dm}^{-3}$; V\% 30.2; MO $55.8 \mathrm{~g} \mathrm{dm}^{-3}$. For cattle manure one obtained $\mathrm{pH} 8.0 \mathrm{CaCl}_{2} ; \mathrm{Ca} 3.5 \mathrm{cmol}_{\mathrm{c}} \mathrm{dm}^{-3}$; $\mathrm{Mg} 9.5 \mathrm{cmol}_{\mathrm{c}} \mathrm{dm}^{-3} ; \mathrm{H}+\mathrm{Al} 0.3 \mathrm{cmol}_{\mathrm{c}} \mathrm{dm}^{-3} ; \mathrm{CTC} 14.6 \mathrm{cmol}_{\mathrm{c}}$ $\mathrm{dm}^{-3}$; P $438.4 \mathrm{mg} \mathrm{dm}^{-3}$; K $9.1 \mathrm{mg} \mathrm{dm}^{-3}$; V\% 97.9; MO $105.3 \mathrm{~g} \mathrm{dm}^{-3}$. Regarding biochar, the results were $\mathrm{pH}$ $5.8 \mathrm{CaCl}_{2} ; \mathrm{Ca} 2.1 \mathrm{cmol}_{\mathrm{c}} \mathrm{dm}^{-3} ; \mathrm{Mg} 0.9 \mathrm{cmol}_{\mathrm{c}} \mathrm{dm}^{-3} ; \mathrm{H}+\mathrm{Al}$ $1.6 \mathrm{cmol}_{\mathrm{c}} \mathrm{dm}^{-3}$; CTC $5.4 \mathrm{cmol}_{\mathrm{c}} \mathrm{dm}^{-3}$; P $9.9 \mathrm{mg} \mathrm{dm}^{-3} ; \mathrm{K}$ $330.0 \mathrm{mg} \mathrm{dm}^{-3}$; V\% 71.0; MO $17.4 \mathrm{~g} \mathrm{dm}^{-3}$.

Vegetal coal was attained from wood of Cerrado native species and made in conventional oven, with temperature ranging from $200{ }^{\circ} \mathrm{C}$ in the first phase to $500{ }^{\circ} \mathrm{C}$ in the final carbonization phase. After the perfect wood carbonization, the material was milled in a rotating knives grinder until its partial homogenization, and, then, sieved in a $1.0 \mathrm{~mm}$ mesh sieve to depart the coarse material remaining from milling and make the product uniform. The milled coal (biochar) was tested regarding the gradation in standard soil sieves, presenting more than $62 \%$ of the material in gradation under $0.5 \mathrm{~mm}$ and approximately $48 \%$ under $0.1 \mathrm{~mm}$. The substrates mixture was performed with the aid of electric mixer for perfect homogenization.

The height, diameter, root length (RL), dry mass of shoot (DMS) and dry mass of root (DMR) parameters were obtained in the $135 \mathrm{DAS}$. The height was measured by a millimeter ruler placed from the soil level to the top. The diameter was measured by a digital caliper ( $0.01 \mathrm{~mm}$ accuracy) at $3 \mathrm{~cm}$ from the soil. The dry weight determination was by the destructive method, where the plants were uprooted, washed and separated into root and stem. The material was placed in paper bags duly identified and dried in a forced circulation stove at $65^{\circ} \mathrm{C}$ for 72 hours until the attainment of constant weight. Samples were weighted on a scale $(0.001 \mathrm{~g})$ right after the drying for preventing the absorption of air humidity. The length of the fresh plants root system was obtained with the aid of a millimeter rule, measuring from the bottom of the main root at the basis of the sample until its edge.

The determination of seedlings quality in each treatment applied the Dickson Quality Index: DQI = total dry mass/(Ratio height/diameter + ratio dry biomass aerial/root) (DICKSON et al., 1960). In order to test the effect of different treatments, a variance analysis was performed, being the averages of significant variables grouped under the Duncan criterion at $5 \%$ of significance.

\section{RESULTS}

Only height, diameter and dry mass of shoots showed significant differences among the substrates. For the average height of the seedling, the substrate composed of larger doses of manure and biochar (CM30 $+\mathrm{BC} 30)$ showed the better results, differing from the control with $9 \%$ increase in height $(2.2 \mathrm{~cm})$. The substrates formed only by doses of biochar (20 and $30 \%$ ) showed lower performance, with an average decrease of $12 \%$ in height compared to the control (3.1 and $2.9 \mathrm{~cm}$, respectively) (Figure 1).

The substrates with $30 \%$ (CM30) and the substrate with $20 \%$ of cattle manure plus $30 \%$ of biochar (CM20 $+\mathrm{BC} 30$ ) showed the highest average values of diameter for seedlings of $M$. pubescens, increasing on $0.24 \mathrm{~mm}$ ( $8 \%$ ) compared to the control. We also observed for the substrate composed of $30 \%$ biochar a decrease in the diameter of the seedlings around $8 \%$ compared to the control (Figure 2).

For dry weight of shoots, the results corroborate those that registered for the height, being the higher levels of manure and biochar (CM30 + BC30) the most effective substrate, with an increase of $26 \%$ biomass

Revista Árvore, Viçosa-MG, v.39, n.4, p.655-661, 2015 
$(0.58 \mathrm{~g})$ compared to the control. The less effective substrate was $30 \%$ of biochar (not mixed), with the registered values of biomass not differing from the control (Figure 3).

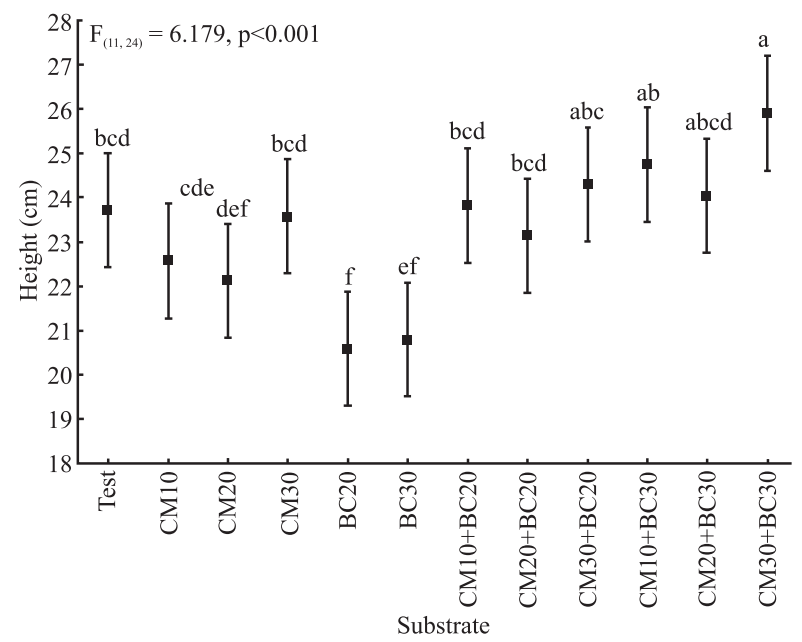

Figure 1-Average height of Magonia pubescens seedlings, at $135 \mathrm{DAS}$, on different substrates using doses of biochar (BC) and cattle manure (CM).

Figura 1-Altura média de mudas de Magonia pubescens aos 135 DAS, em diferentes substratos, usando doses de biochar (BC) e esterco bovino (CM).

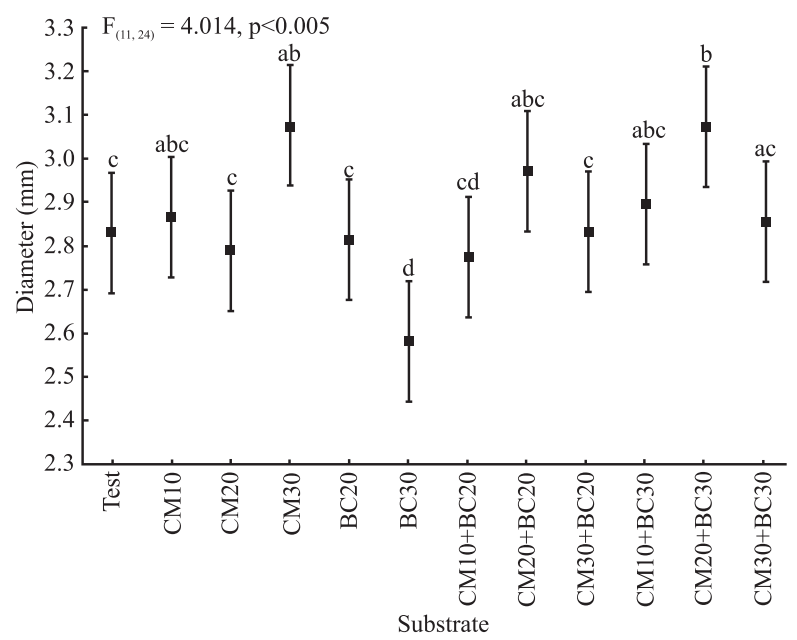

Figure 2 - Average diameter of Magonia pubescens seedlings at $135 \mathrm{DAS}$, on different substrates using doses of biochar (BC) and cattle manure (CM).

Figura 2 - Diâmetro médio de mudas de Magonia pubescens aos 135 DAS, em diferentes substratos, usando doses de biochar (BC) e esterco bovino (CM).

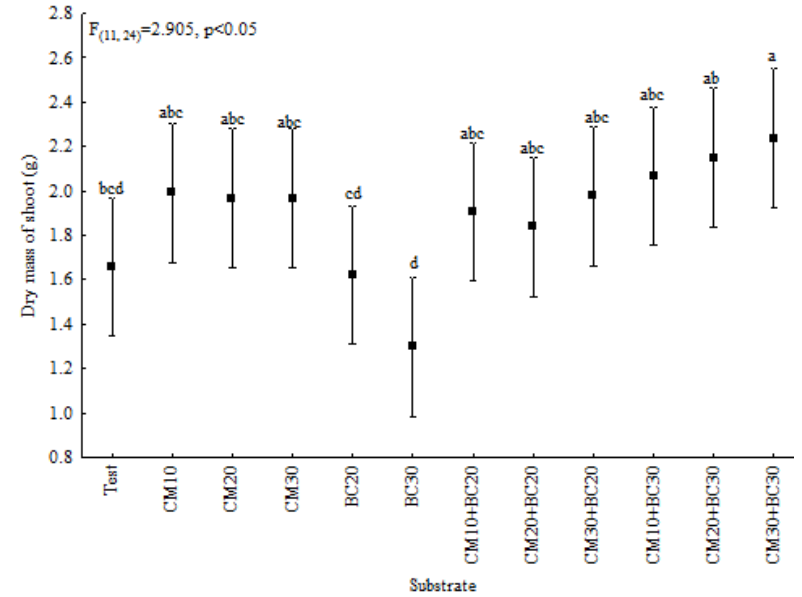

Figure 3 - Dry mass of shoot (g) of Magonia pubescens seedlings at 135 DAS, on different substrates using doses of biochar (BC) and cattle manure (CM).

Figura 3-Massa seca da parte aérea (g) de mudas de Magonia pubescens aos 135 DAS, em diferentes substratos, usando doses de biochar (BC) e esterco bovino (CM).

The observed data corroborate the hypothesis that substrates formed with doses of biochar and a source of nutrients are effective for the better growth of seedlings of $M$. pubescens. However, as we did not observe significant differences for the different substrates for the root biomass and DQI ( $p>0.05)$, the proposed higher performance for these substrates did not hold. Although these substrates did not influence the quality of seedlings (DQI), we observed that the substrates formed only by doses of biochar (not mixed) added to soils are detrimental to the growth of the seedlings.

\section{DISCUSSION}

Studies like those of Gaskin et al. (2010), Glaser et al. (2002), Marimon-Junior et al. (2012), Petter et al. (2012), and Steiner et al. (2007), confirm the existence of positive effects in the combination of biochar and a fertilizer, being superior to the use of the product in an isolated way to promote the vegetal development and the culture productivity. Those statements are confirmed in this study, proving that the use of biochar in isolation do not give the applicable efficiency to the vegetal production (GLASER et al., 2002; STEINER et al., 2007; GASKIN et al., 2010; MARIMON-JUNIOR et al., 2012; PETTER et al., 2012; LIMA et al., 2013b). 
This is due to its ability to retain water and nutrients promoted by its porous structure and long persistence in the soil, which causes a decrease in leaching and increase cation exchange capacity, further improving the growth characteristics and crop (GLASER et al., 2002; LEHMANN, 2007; LEHMANN; JOSEPH, 2009).

Considering that biochar is not a source of nutrients (WINSLEY, 2007), the product shows low efficiency when added alone, as observed in this study with the addition of doses of biochar in a Latosol. Some results can be distinct due to the chemical characteristics of the base substrate, which may be adequate to act on the available nutrient retention and promote the improvement of plant development without the need for addiction of an extra source of nutrients. In a work made with seedlings of Tachigali paniculata, a Brazilian tree species, the addition of biochar in varied doses to the substrate was found to promote improvement in the seedlings development (SOUCHIE et al., 2011), differently from the results observed here, where biochar benefited the seedlings development only related to cattle manure.

According to Melo et al. (1998), Cerrado species, even though adapted to the low fertility soils conditions, present significant response to fertilizing, in particular in the seedling phase, the addition of nutrient sources like cattle manure, or of soil conditionings, like biochar, being, therefore, efficient. According to Artur et al. (2007), organic fertilizers are more frequently used in the composition of substrates for production of seedlings, since, in addition to influencing on quality, they are easy to find, being an alternative source to reduce production costs. However, some species show no significant increase in development when subjected to fertilization, which may be a feature of their genetic variability in response to low natural fertility of the soil in which they are adapted. This condition could contribute to the lack of differences between the substrates in terms of quality of seedlings. These results of the Dickson Quality Index may have been influenced by the root biomass, since this compartment was the only parameter that showed no differences between the substrates. This condition can be related to the production of seedlings in plastic bags, which reduce the growth area of the roots, forcing the plant to invest more in aboveground growth, since it does not require root growth to reach water and nutrients needs. Field trials or in larger containers may provide different results, since they provide better conditions for root development, which may result in differences between the substrates for root biomass and seedling quality.

Even without distinction between treatments for the DQI, we observed improvement of plant growth in substrates formed with doses of biochar and manure, specially for the height and diameter of seedlings. These two morphologic characteristcs are the most important for determining the seedlings growth in field conditions (PEREIRA et al., 2010). Thus is possible to assume that biochar and manure acting in concert can promote the potential of the soil or substrate for the production of good performance seedlings and with promising development after the transplant. This study confirms that biochar is efficient, at least for growth in height and diameter of seedlings, but also in association with fertilizers of organic source, as the cattle manure.

The dry matter and the diameter of the seedlings are strongly correlated with DQI, allowing the use of these parameters to predict the quality of seedlings (BINOTTO et al., 2010). Thus, such variables allow to validate the hypothesis that substrates formed with addition of cattle manure and biochar are efficient for the production of seedlings of M. pubescens. Moreover, considering that the seedlings need to present an average of $30 \mathrm{~cm}$ of heigth for planting in the field (SCREMINDIAS, 2006), the substrates formed by the doses of both materials were those that provided more adequate seedlings for replanting.

As differences in plant growth between doses were observed, it is necessary to establish appropriate doses for each type of crop and cultivated species, since the product may appear inefficient or harmful as used in inadequate proportions or field conditions (GLASER et al., 2002; ZANETTI et al., 2003). Attention should be paid as well to the different production and materials conditions from which biochar originates, causing variations in the characteristics of the end product and, thus, in its activity on the soil characteristics (GASKIN et al., 2010; LEHMANN, 2007).

\section{CONCLUSIONS}

The doses of cattle manure and biochar, when related, improve the height, diameter and dry mass of shoot parameters, the dose of $30 \%$ being the most efficient.

Revista Árvore, Viçosa-MG, v.39, n.4, p.655-661, 2015 
The substrates formed only by doses of biochar were not effective to improve the growth parameters of seedlings.

As the diameter is considered a robust predictor for quality seedlings, we validate the hypothesis that the substrates formed with added doses of cattle manure and biochar are efficient for the production of seedlings of $M$. pubescens.

\section{REFERENCES}

ALMEIDA, S. P.; PROENÇA, C. E. B.; SANO, S. M.; RIBEIRO, J. F. Cerrado:espécies vegetais úteis. Planaltina: Embrapa, 1998. 464p.

ARTUR, A. G.; CRUZ, M. C. P.; FERREIRA, M. E.; BARRETTO, V. C. M.; YAGIM, R. Esterco bovino e calagem para formação de mudas de guanandi. Pesquisa Agropecuária Brasileira, v.42, n.6, p.843-850, 2007.

BENITES, V. M.; TEIXEIRA, W. G.; REZENDE, M. E.; PIMENTA, A. S. Utilização de carvão e subprodutos da carbonização vegetal na agricultura: aprendendo com as Terras Pretas de Índio. In: TEIXEIRA, W. G.; KERN, D. C.; MADARI, B. E.; LIMA, H. N.; WOODS, W. I. (Ed.). As Terras Pretas de åndio da Amazônia: sua caracterização e uso deste conhecimento na criação de novas áreas. Manaus: Embrapa Amazônia Ocidental, 2009. p.285-296.

BINOTTO, A. F.; LÚCIO, A. D. C.; LOPES, S. J. Correlations between growth variables and the Dickson Quality Index in forest seedlings.

Cerne, v.16, n.4, p.457-464, 2010.

CAMPOS FILHO, E. M. Plante as árvores do Xingu e Araguaia: guia de identificação. São Paulo: ISA, 2009. 300p.

DICKSON, A.; LEAF, A. L.; HOSNER, J. F. Quality appraisal of white spruce and white pine seedling stock in nurseries. Forest Chronicle, v.36, n. 1, p.10-13, 1960.

GASKIN, J. W.; SPEIR, R. A.; HARRIS, K.; DAS, K. C.; LEE, R. D.; MORRIS, L. A.; FISHER, D. S. Effect of peanut hull and pine chip biochar on soil nutrients, corn nutrient status, and yield. Agronomy Journal, v.102, n.2, p.623-633, 2010.

Revista Árvore, Viçosa-MG, v.39, n.4, p.655-661, 2015
GLASER, B.; LEHMANN, J.; ZECH, W. Ameliorating physical and chemical properties of highly weathered soils in the tropics with charcoal - a review. Biology and Fertility of Soils, v.35, p.219-230, 2002.

LEHMANN, J. Bio-energy in the black. Frontiers in ecology and the environment, v.5, p.381-387, 2007.

LEHMANN, J.; JOSEPH, S. Biochar for environmental management: an introduction. In: LEHMANN, J.; JOSEPH, S. (Ed.). Biochar for environmental management: science and technology. London: Earthscan, 2009. p.01-09.

LIANG, B.; LEHMANN, J.; SOLOMON, D.; KINYANGI, J.; GROSSMAN, J.; O’NEILL, B.; SKJEMSTAD, J. O.; THIES, J.; LUIZÃO, F. J.; PETERSEN, J.; NEVES, E. G. Black carbon increases cation exchange capacity in soils. Soil Science Society of America Journal, v.70, p.719-1730, 2006.

LIMA, S. L.; MARIMON-JUNIOR, B. H.; PETTER, F. A.; TAMIOZZO, S.; BUCK, G. B.; MARIMON, B. S. Biochar as substitute for organic matter in the composition of substrates for seedlings.

Acta Scientiarum Agronomy, v.35, n.3, p.333-341, 2013a.

LIMA, S. L.; TAMIOZZO, S.; PETTER, F. A.; MARIMON, B. S.; MARIMON-JUNIOR, B. H. Desenvolvimento de mudas de beterraba em substratos comerciais tratados com biochar.Agrotrópica, v.25, p.181-186, 2013 b.

MACEDO, M. C.; SCALON, S. P. Q.; SARI, A. P.; SCALON FILHO, H.; ROSA, Y. B. C. J.; ROBAINA, A. D. Biometria de frutos e sementes e germinação de MagoniapubescensSt. Hil (Sapindaceae). Revista Brasileira de Sementes, v.31, n.2, p.202-211, 2009.

MARIMON-JUNIOR, B. H.; PETTER, F. A.; ANDRADE, F.; MADARI, B. E.; MARIMON, B. S.; SCHOSSLER, T. R.; GONÇALVES, L. G. V.; BELÉM, R. S. Produção de mudas de jiló em substrato condicionado com Biochar. Comunicata Scientiae, v.3, n.2, p.108-114, 2012.

MELO, J. T.; SILVA, J. A.; TORRES, R. A. A.; SILVEIRA, C. E. S.; CALDAS, L. S. Coleta, propagação e desenvolvimento inicial de espécies 
do Cerrado. In: SANO, S. M.; ALMEIDA, S. P. (Ed.). Cerrado: ambiente e flora. Planaltina: Embrapa, 1998. p.191-243.

PEREIRA, P. C.; MELO, B.; FREITAS, R. S.; TOMAZ, M. A.; TEIXEIRA, I. R. Tamanho de recipientes e tipos de substrato na qualidade de mudas de tamarindeiro. Revista Verde, v.5, p.136-142, 2010.

PETTER, F. A.; MADARI, B. E.; SOLER, M. A. S.; CARNEIRO, M. A. C.; CARVALHO, M. T. M.; MARIMON-JUNIOR, B. H.; PACHECO, L. P. Soil fertility and upland rice yield after biochar application in the Cerrado. Pesquisa Agropecuária Brasileira, v.47, n.5, p.699$706,2012$.

SCREMIN-DIAS, E.; KALIFE, C.; MENEGUCCI, Z. R. H.; SOUZA, P. R. Produção de mudas de espécies florestais nativas: manual. Campo Grande: UFMS, 2006. 59p.

SOUCHIE, F. F.; MARIMON-JUNIOR, B. H.; PETTER, F. A.; MADARI, B. E.; MARIMON, B. S.; LENZA, E. Carvão pirogênicocomo condicionante para substrato de mudas de Tachigalivulgaris L.G. Silva \& H.C. Lima. Ciência Florestal,v.21, n.4, p.811-821, 2011.

SOUZA, C. D.; FELFILI, J. M. Uso de plantas medicinais na região de Alto Paraíso de Goiás, GO, Brasil. ActaBotanicaBrasílica,v.20, n.1, p.135-142, 2006.

STEINER, C.; TEIXEIRA, W. G.; LEHMANN, J.; NEHLS, T.; MACÊDO, J. L. V.; BLUM, W. E. H.; $\mathrm{ZECH}, \mathrm{W}$. Long term effects of manure, charcoal and mineral fertilization on crop production and fertility on a highly weathered Central Amazonian upland soil. Plant Soil, v.291, p.275-290, 2007.

WINSLEY, P. Biochar and bioenergy production for climate change mitigation. Science Review, v.64, n.1, p.05-10, 2007.

ZANETTI, M.; CAZETTA, J. O.; MATTOS

JÚNIOR, D.; CARVALHO, S. A. Uso de subprodutos de carvão vegetal na formação do porta-enxerto limoeiro 'Cravo' em ambiente protegido. Revista Brasileira de Fruticultura,v.25, n.3, p.508-512, 2003. 